\title{
An Economic Analysis of Cashewnut Production in Konkan Region of Maharashtra, India
}

\author{
Mahantesh Nayak* and Manjunatha Paled \\ Department of Agricultural Economics, College of Agriculture, Dharwad, UAS, \\ Dharwad - 580 005, Karnataka, India \\ *Corresponding author
}

\section{Keywords}

Cashew, Establishment cost, Net returns, NPV, IRR and Payback period

Article Info

Accepted:

24 November 2018

Available Online:

10 December 2018

\section{A B S T R A C T}

Cashew is known as 'maintenance free' crop. Due to improvement in health consciousness of people cashew is gaining importance not only in domestic markets but also in international markets. The study was conducted in Konkan region of Maharashtra and is based on both primary and secondary data collected from 120 respondents and data were analyzed by using standard statistical tools (i) compound annual growth rates (CAGR)and graphical representations to draw the overview of trends in area, production and productivity of cashew in India and Maharashtra (ii) budgeting technique to work out the economics of cashew cultivation (iii) financial feasibility tests to know the feasibility of investment in cashew plantation. The study revealed that both area and production of cashew has been increasing in the country as well as in Maharashtra over the past years. The establishment cost (initial investment cost and maintenance cost during gestation period) accounted to Rs. 1,19,287/ha in Ratnagiri and Rs. 1,31,155/ha in Sindhudurga district. Cost of cultivation during bearing period was Rs. 55,054/ha in Ratnagiri and Rs. $68,858 /$ ha in Sindhudurga. Average market price of raw cashew was higher in Sindhudurga district. Gross returns was Rs. 2,78,775/ha in Ratnagiri and Rs. 3,44,700 in Sindhudurga and net return was Rs. 2,25,380 and Rs. 2,79,206. Feasibility analysis revealed that, the NPV @ 12 percent discount rate, BCR, IRR and payback period were Rs. 9,72,207 and Rs. 11,38,561, 3.95 and 3.86, 65.68\% and 68.73\% and 5.7 years and 5.6 years respectively in Ratnagiri and Sindhudurga districts. Therefore, investment in cashew was financially feasible in both the districts of Konkan Maharashtra.

\section{Introduction}

The cashew tree (Anacardium occidentale L.), native of Brazil, was introduced to Mozambique and then to India in the sixteenth century by the Portuguese as a means of controlling coastal erosion. It is interesting to note that cashew spread within these countries with the aid of elephants that ate the bright cashew fruit along with the attached nut. The nut was too hard to digest and was later expelled with the droppings. It was not until the nineteenth century that plantations were developed and the tree then spread to a number of other countries in Africa, Asia and Latin America (Harish, 2009). Subsequently, 
the tree spread to a number of countries in Africa, Asia, Latin America and West Indies. Cashew is now widely cultivated for its kernel, fruit, cashew nut shell liquid and other products. However, it is mostly found in the coastal regions of South Africa, Madagascar, Tanzania, and South Asia, from Sri Lanka to the Philippines.

India is the largest producer, processer, consumer and exporter of cashew in the world (Elakkiya et al., 2017). The current Cashewnut production in India accounts for 45 per cent of the global production. India being the leader in the world in raw Cashew nut production and is also the largest supplier of cashew kernels to the major world markets. It is grown in Kerala, Karnataka, Goa, and Maharashtra along the West coast and Tamil Nadu, Andhra Pradesh, Odissa and West Bengal along the East-coast, occupies an area of 10.30 lakh hectares in the country with a production of 9.98 lakh metric tonnes.

Even though strong competition from other countries has reduced India's share in the global cashew exports, India's advantage in terms of less percentage of broken kernels has brought European and US buyers to its proximity. To strengthen cashew exports, there is scope for increasing production by developing cashew as plantation crop on commercial basis, exploring new markets and strengthening non-traditional markets, adding value to the product by introducing innovations in processing and branding them. Among the major states in the country, Maharashtra tops with respect to area, production and productivity of cashew nut. During 2016-17, area under Cashewnut in Maharashtra was 186.20 thousand hectares producing 256.61 thousand tonnes with yield of $1378 \mathrm{~kg}$ per hectares.

Keeping in view the importance of cashew in the Indian economy in general and its major growing states in particular, the present study made an attempt to analyze the cost and returns structure involved in production and processing of Cashewnut in Konkan region of Maharashtra.

\section{Materials and Methods}

\section{Nature and sources of data}

The study is based on both primary and secondary data. Primary data was collected from farmer-respondents of Maharashtra and secondary data collected from different source like www.indiastat.com and district agriculture office, Ratnagiri and Sindhudurga etc. for achieving the objectives of the study.

\section{Sampling procedure}

Multistage sampling technique was adopted in the selection of the districts, taluks, villages and cashew growers. Keeping in view the objectives of the study, two districts viz., Sindhudurga and Ratnagiri districts were selected as these two districts were the major districts of cashew plantation in Maharashtra state.

From each selected district two taluks, from each taluk two villages and from each village 15 farmers were selected. Thus, in all 120 cashew growers were selected to collect the required information. Dodamarga and Sawanthwadi taluks in Sindhudurga district and in Ratnagiri district Lanja and Rajapurtaluks were selected for farmer's survey.

\section{Analytical tools}

For the purpose of evaluating the objectives of the study, based on the nature and extent of data availability, the following analytical tools will be used for analyzing the data to draw meaningful results and conclusions. 
Descriptive analysis

To workout the averages and percentages

Compound annual growth rate analysis.

To study the annual growth rate in quantity and value of export of coir products, the compound growth rate was computed using semi-log or exponential model (Kulkarni et. al. 2012).

$\ln \mathrm{Y}_{\mathrm{t}}=\alpha+\beta_{\mathrm{t}}+\mathrm{u}_{\mathrm{t}}$

Where,

$Y_{t}=$ Quantity (tonnes) of coir products exported in year $\mathrm{t}$.

$\mathrm{t}=$ Time element which takes the value 1,2 $\mathrm{n}$ for various years.

$\alpha=$ Intercept

$\beta_{\mathrm{t}}=$ Regression co-efficient

Annual compound growth rate $(\mathrm{r})=[$ (Antilog $\left.\left.\left.\beta_{\mathrm{t}}\right)-1\right) \times 100\right]$

Budgeting technique

To workout the cost and returns involved in Cashewnut production

Estimation of Financial feasibility

For estimation of financial feasibility, Net Present Value (NPV), internal rate of return (IRR) and benefit-cost ratio (BCR) were assessed using the technique given by Gittinger (1974).

\section{Results and Discussion}

The findings of the present study as well as appropriate discussion have been summarized under following heads:
Decade-wise growth in area, production and yield of Cashew in India

In India, cashew cultivation is largely found in Kerala, Karnataka, Goa and Maharashtra along the west coast and Tamil Nadu, Andhra Pradesh, Orissa and West Bengal along the east coast. The decade-wise growth in the area, production and productivity are presented in Table 1. It is seen from the table that the compound annual growth rate (CAGR) for area was found to be highest during $1990-91$ to $1999-00$ (3.65\% per year). This might be due to economic liberalization which affected indirectly the cultivation of cashew, followed by 2.55 per cent per annum during 2000-01 to 2009-10, 1.74 per cent per year during $1980-81$ to $1989-90$ and 1.53 per cent per annum during 2010-11 to 2017-18. The growth in production was found to be highest during pre-economic liberalization period i.e., during 1980-81 to 1989-90 (8.80\% per year)followed by 4.55 per cent per year during 2000-01 to 2009-10, 3.14 per cent per annum during $1990-91$ to $1999-00$ and 1.89 per cent during 2010-11 to 2017-18. While the average annual growth in yield of cashew was found to be highest during 1980-81 to $1989-90$ (6.93\% per year) followed by 1.95 per cent per year during 200-01 to 2009-10, 0.45 per cent during 2010-11 to 2017-18 and there was a negative growth during 1990-91 to 1999-00. We can see a decreasing growth rate in yield over decades. The major reasons attributing to low productivity in the country might be due to:

Use of low yielding local varieties

Planting of cashew in marginal and poor fertile land

Non-adoption of recommended package of practices

Pest infestation (tea mosquito bug and cashew stem and root borer) leading to yield reduction up to 30 to 40 percent (Kulkarni et al., 2012). 
Growth in area, production and productivity of Cashewnut in Maharashtra

Year-wise area, production and productivity are presented in Table 2. It seen that during 1993-94, the area under Cashewnut in Maharashtra was 51 thousand hectares and has increased almost four folds (186.20 thousand hectares) with an average annual growth of 4.98 per cent. With respect to cashew production, during 1993-94 in Maharashtra 47 thousand tonnes of cashew has been produced which has increased more than five folds to reach 257 thousand tonnes during 2016-17 with an annual growth rate of 7.77 per cent. While yield was found to be only $1246 \mathrm{~kg} / \mathrm{ha}$ during 1993-94 and has increased gradually with some fluctuations over the years to 1378 $\mathrm{kg} / \mathrm{ha}$ with a declining growth rate of -0.03 per cent per year. This might be due to the universal law of diminishing marginal returns.

\section{Establishment Cost of Cashewnut plantation}

Establishment of cashew plantation includes investment cost and maintenance cost and is presented in Table 3.

\section{Initial investment cost (First year)}

In Ratnagiri district, total investment cost was found to be Rs. 50,960 (42.72\% of the total establishment cost).Among investment components cost of pump set was found to be Rs. 14, 925, cost on digging bore well was Rs. 11,550, rental value was found to be Rs. 9275, cost of planting materials was Rs. 7585, cost on drip pipes was Rs. 5650 and cost of digging pits and for planting was Rs. 1250.

Whereas in Sindhudurga district, total investment cost was found to be Rs. 56,705 $(42.24 \%$ of the total establishment cost).Among investment components cost of pump set was found to be Rs. 15, 500, cost on digging bore well was Rs. 12,755, rental value was found to be Rs. 11,575, cost of planting materials was Rs. 8750 , cost on drip pipes was Rs. 5650 and cost of digging pits and for planting was Rs. 1425. Whereas in the findings of Guledagudda (2005) the total establishment cost was found to be Rs. 38,697.

\section{Maintenance cost during gestation period (from second year to fourth year)}

The maintenance cost incurred by the Cashewnut growers in during the gestation period is presented in the Table 3 . The results revealed that in Ratnagiri district, total maintenance cost during gestation period (up to fourth year) accounted to Rs. 68,337 of which cost of Rs. 20,182, Rs. 22,603, andRs. 25,542 occurred during second, third and fourth years respectively. Hence the total establishment cost was summed to Rs. $1,19,287$.

Whereas in Sindhudurga district, total maintenance cost during gestation period (up to fourth year) accounted to Rs. 74,450 of which cost of Rs. 23,460, Rs. 24,350 andRs. 26,640 occurred during second, third and fourth years respectively. Hence the total establishment cost was accounted to Rs. $1,31,155$.

It is observed from that total establishment cost of cashew plantation was highest in Sindhudurga district compared to Ratnagiri district mainly because of the high labour cost in Sindhudurga district attributed by scarcity of labour.

\section{Cost of cultivation of cashewnut plantation $\left(5^{\text {th }}\right.$ year onwards)}

The cost of cultivation of Cashewnut in Ratnagiri district is presented in Table 4. In Ratnagiri district, total cost incurred in cultivation of cashew plantation was found to 
be Rs. 55,054 of which variable cost accounts Rs.40,139 (72.91\% of the total cost)and fixed cost accounts Rs. 14,915 (27.09\% of the total cost). Variable cost includes labour cost (Rs. 20,907), material cost (Rs. 15,583) and managerial cost @ 10\% on variable cost (Rs. 3649).

Among labour cost, harvesting cost was found to be highest accounting Rs. 11,055 followed by cost of weeding accounting to Rs. 3252 . Fixed cost constitutes rental value (Rs. 12,650) and depreciation of fixed capital (Rs. 2265). Whereas in Sindhudurga district, total cost incurred in cultivation of cashew plantation was found to be Rs. 68,858 of which variable cost accounts Rs. 48,716 (73.97\% of the total cost) and fixed cost accounts Rs. 17,142 (26.03\% of the total cost). Variable cost includes labour cost (Rs. 26,572), material cost (Rs. 17,715) and managerial cost @ 10\% on variable cost (Rs. 4429). Among labour cost, harvesting cost was found to be highest accounting Rs. 14,364 followed by cost of weeding accounting to Rs. 3875. Fixed cost constitutes rental value (Rs. 14,830) and depreciation of fixed capital (Rs. 2312) (Fig. 1).

Table.1 Decade-wise growth in area, production and yield of cashew in India

\begin{tabular}{|l|c|c|c|}
\hline CAGR $(\%)$ & Area & Production & Yield \\
\hline $\mathbf{1 9 8 0 - 8 1}$ to $\mathbf{1 9 8 9 - 9 0}$ & 1.74 & 8.8 & 6.93 \\
\hline $\mathbf{1 9 9 0 - 9 1}$ to $\mathbf{1 9 9 9 - 0 0}$ & 3.65 & 3.14 & -0.49 \\
\hline $\mathbf{2 0 0 0 - 0 1}$ to $2009-10$ & 2.55 & 4.55 & 1.95 \\
\hline $\mathbf{2 0 1 0}-11$ to $2017-18$ & 1.53 & 1.89 & 0.45 \\
\hline
\end{tabular}

Source: www.indiastat.com

Table.2 Area, production and productivity of cashewnut in Maharashtra (2002-03 to 2016-17)

\begin{tabular}{|c|c|c|c|c|c|c|c|}
\hline Years & $\begin{array}{c}\text { Area } \\
(\mathbf{0 0 0} \text { ha) }\end{array}$ & $\begin{array}{c}\text { Production } \\
(\mathbf{0 0 0} \mathbf{M T})\end{array}$ & $\begin{array}{c}\text { Yield } \\
(\mathbf{k g} / \mathbf{h a})\end{array}$ & Years & $\begin{array}{c}\text { Area } \\
(\mathbf{0 0 0} \mathbf{h a})\end{array}$ & $\begin{array}{c}\text { Production } \\
(\mathbf{0 0 0} \mathbf{M T})\end{array}$ & $\begin{array}{c}\text { Yield } \\
(\mathbf{k g} / \mathbf{h a})\end{array}$ \\
\hline $\mathbf{1 9 9 3 - 9 4}$ & 51 & 47 & 1246 & $2006-07$ & 164 & 197 & 1500 \\
\hline $\mathbf{1 9 9 4 - 9 5}$ & 58 & 38 & 1100 & $2007-08$ & 167 & 210 & 1500 \\
\hline $\mathbf{1 9 9 5 - 9 6}$ & 67 & 69 & 1440 & $2008-09$ & 170 & 225 & 1323 \\
\hline $\mathbf{1 9 9 6 - 9 7}$ & 80 & 80 & 1570 & $2009-10$ & 175 & 198 & 1186 \\
\hline $\mathbf{1 9 9 7 - 9 8}$ & 104 & 60 & 1500 & $2010-11$ & 181 & 208 & 1231 \\
\hline $\mathbf{1 9 9 8 - 9 9}$ & 119 & 85 & 1500 & $2011-12$ & 183 & 223 & 1282 \\
\hline $\mathbf{1 9 9 9 - 0 0}$ & 121 & 125 & 1470 & $2012-13$ & 184 & 225 & 1282 \\
\hline $\mathbf{2 0 0 0 - 0 1}$ & 121 & 98 & 1050 & $2013-14$ & 184 & 236 & 1317 \\
\hline $\mathbf{2 0 0 1 - 0 2}$ & 143 & 103 & 880 & $2014-15$ & 186 & 235 & 1262 \\
\hline $\mathbf{2 0 0 2 - 0 3}$ & 148 & 110 & 1000 & $2015-16$ & 186.2 & 220 & 1200 \\
\hline $\mathbf{2 0 0 3 - 0 4}$ & 148 & 120 & 1100 & $2016-17$ & 186.2 & 257 & 1378 \\
\hline $\mathbf{2 0 0 4 - 0 5}$ & 160 & 174 & 1200 & $\mathbf{C A G R}$ & $\mathbf{4 . 9 8}$ & $\mathbf{7 . 7 7}$ & $\mathbf{- 0 . 0 3}$ \\
\hline $\mathbf{2 0 0 5 - 0 6}$ & 160 & 183 & 1300 & $\mathbf{( \% )}$ & & & \\
\hline
\end{tabular}


Table.3 Establishment cost of cashew plantation

\begin{tabular}{|c|c|c|c|c|c|}
\hline \multirow[t]{2}{*}{ Sl. No. } & \multirow[t]{2}{*}{ Particulars } & \multicolumn{2}{|c|}{ Ratnagiri } & \multicolumn{2}{|c|}{ Sindhudurga } \\
\hline & & Cost (Rs.) & Per cent & Cost (Rs.) & Per cent \\
\hline A & Investment cost & & & & \\
\hline 1 & Rental value & 9275 & 7.78 & 11,575 & 8.83 \\
\hline 2 & Borewell & 11,550 & 9.68 & 12,755 & 9.73 \\
\hline 3 & Pump set & 14,925 & 12.51 & 15,500 & 11.82 \\
\hline 4 & Planting materials & 7585 & 6.36 & 8750 & 6.67 \\
\hline 5 & Drip pipes & 5650 & 4.74 & 5650 & 4.31 \\
\hline 6 & Stakings & 725 & 0.61 & 1050 & 0.80 \\
\hline \multirow[t]{2}{*}{7} & Digging of pit \& planting & 1250 & 1.05 & 1425 & 1.09 \\
\hline & Sub Total & 50,960 & 42.72 & 56,705 & 43.24 \\
\hline \multirow[t]{6}{*}{ B } & Maintenance cost & & & & \\
\hline & Year-II & 20,182 & 16.92 & 23,460 & 17.89 \\
\hline & Year-III & 22,603 & 18.95 & 24,350 & 18.57 \\
\hline & Years-IV & 25,542 & 21.41 & 26,640 & 20.31 \\
\hline & Sub Total (II+III+IV) & 68,327 & 57.28 & 74,450 & 56.76 \\
\hline & Total Establishment cost $(A+B)$ & $1,19,287$ & 100.00 & $1,31,155$ & 100.00 \\
\hline
\end{tabular}

Table.4 Cost of cultivation of cashewnut during bearing period (5th year onwards)

\begin{tabular}{|c|c|c|c|c|c|}
\hline \multirow[t]{2}{*}{ Sl. No. } & \multirow[t]{2}{*}{ Particulars } & \multicolumn{2}{|c|}{ Ratnagiri } & \multicolumn{2}{|c|}{ Sindhudurga } \\
\hline & & Value & Per cent & Value & Per cent \\
\hline I & Variable cost & & & & \\
\hline A & Labour cost & & & & \\
\hline 1 & Ploughing/ harrowing & 1558 & 2.83 & 1856 & 2.82 \\
\hline 2 & Pruning & 1275 & 2.32 & 1798 & 2.73 \\
\hline 3 & Application of FYM \& Fertilizers & 1556 & 2.83 & 1764 & 2.68 \\
\hline 4 & Application of PPC & 1456 & 2.64 & 1675 & 2.54 \\
\hline 5 & Weeding & 3252 & 5.91 & 3875 & 5.88 \\
\hline 6 & Irrigation & 755 & 1.37 & 1240 & 1.88 \\
\hline \multirow[t]{2}{*}{7} & Harvesting & 11,055 & 20.08 & 14,364 & 21.81 \\
\hline & Total labour cost (a) & 20,907 & 37.98 & 26,572 & 40.35 \\
\hline B & Material Cost & & & & \\
\hline 1 & FYM & 4295 & 7.80 & 3678 & 5.58 \\
\hline 2 & Fertilizers & 5058 & 9.19 & 6984 & 10.60 \\
\hline \multirow[t]{5}{*}{3} & PPC & 6230 & 11.32 & 7053 & 10.71 \\
\hline & Total material cost (b) & 15,583 & 28.30 & 17,715 & 26.90 \\
\hline & Subtotal $(a+b)$ & 36,490 & 66.28 & 44,287 & 67.25 \\
\hline & Managerial cost @ 10\% of $(a+b)$ & 3649 & 6.63 & 4429 & 6.72 \\
\hline & Total Variable cost & 40,139 & 72.91 & 48,716 & 73.97 \\
\hline II & Fixed cost & & & & \\
\hline 1 & Rental value & 12,650 & 22.98 & 14,830 & 22.52 \\
\hline \multirow[t]{3}{*}{2} & Depreciation & 2265 & 4.11 & 2312 & 3.51 \\
\hline & Total fixed cost & 14,915 & 27.09 & 17,142 & 26.03 \\
\hline & Total cost $(I+I I)$ & 55,054 & 100.00 & 65,858 & 100.00 \\
\hline
\end{tabular}


Table.5 Yields obtained and returns realized in cashewnut (5th year onwards)

\begin{tabular}{|r|l|c|c|c|c|}
\hline S. No & \multicolumn{1}{|c|}{ Particulars } & \multicolumn{2}{c|}{ Ratnagiri } & \multicolumn{2}{c|}{ Sindhudurga } \\
\cline { 2 - 6 } & \multicolumn{1}{|c|}{ Kg } & Per cent & Kg & Per cent \\
\hline 1. & Yield obtained in nuts & & & & \\
\hline & a) February & 283 & 15.00 & 360 & 16.00 \\
\hline & b) March & 491 & 26.00 & 580 & 25.78 \\
\hline & c) April & 585 & 31.00 & 680 & 30.22 \\
\hline & d) May & 529 & 28.00 & 630 & 28.00 \\
\hline & \multicolumn{1}{|c|}{ Total yield (Kg/ ha) } & $\mathbf{1 8 9 0}$ & $\mathbf{1 0 0 . 0 0}$ & $\mathbf{2 2 5 0}$ & $\mathbf{1 0 0 . 0 0}$ \\
\hline 2. & Average price/kg of nuts & 147.50 & - & 153.20 & - \\
\hline 3. & Gross returns (Rs.) & $2,78,775$ & - & $3,44,700$ & - \\
\hline 4. & Cost of cultivation (Rs.) & $\mathbf{5 3 , 3 9 5}$ & - & 65,494 & - \\
\hline 5. & Net returns (Rs.) & $\mathbf{2 , 2 5 , 3 8 0}$ & - & $\mathbf{2 , 7 9 , 2 0 6}$ & - \\
\hline
\end{tabular}

Table.6 Financial feasibility of investment in cashewnut production in Maharashtra

\begin{tabular}{|c|c|c|c|}
\hline SI. No. & Particulars & Ratnagiri & Sindlhudurga \\
\hline 1 & NPV (Rs./ha) & $9,72,207$ & $11,38,561$ \\
\hline 2 & B:C ratio & 3.95 & 3.86 \\
\hline 3 & IRR (\%) & 65.68 & 68.73 \\
\hline 4 & PBP (Years) & 5.7 & 5.6 \\
\hline
\end{tabular}

Fig.1 Trends in area, production and yield of cashew (1980-81 to 2017-18)

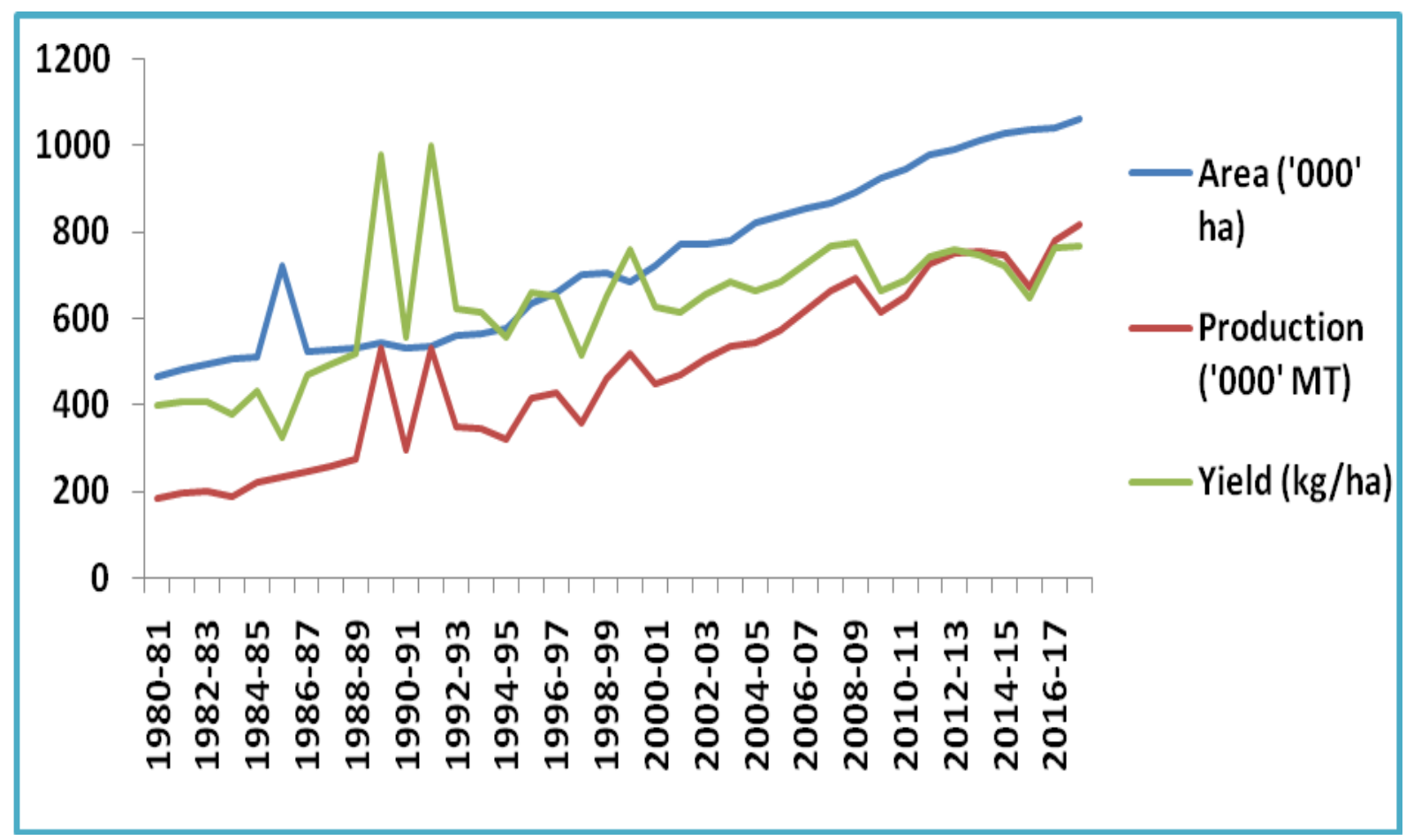


Yield and returns realized in cashewnut during bearing period $\left(5^{\text {th }}\right.$ year onwards)

The Cashewnut growers harvested cashew fruits/nuts for a period of four months (February, March, April and May) in a year. The yields obtained and returns realized from the sale of Cashewnut are presented in the Table 5. It could be seen from the table that in Ratnagiri district, average yield obtained by the farmers was $283 \mathrm{~kg} / \mathrm{ha}$ in February $(15 \%$ of the total yield), $491 \mathrm{~kg} / \mathrm{ha}$ in March (26\% of the total yield), $585 \mathrm{~kg} / \mathrm{ha}$ in April (31\% of the total yield) and $529 \mathrm{~kg} / \mathrm{ha}$ in May (28\% of the total yield) and total of $1890 \mathrm{~kg}$ of raw Cashewnut per ha. Average price obtained was Rs. $147.50 / \mathrm{kg}$ of raw nuts. Farmers realized higher gross return of Rs. 2,78,775/ ha and net return of Rs. 2,25,380/ha.

Whereas in Sindhudurga district, average yield obtained by the farmers was $360 \mathrm{~kg}$ in February (16\%), $580 \mathrm{~kg} / \mathrm{ha}$ in March $(25.78 \%), 680 \mathrm{~kg} / \mathrm{ha}$ April (30.22\%) and 630 $\mathrm{kg} / \mathrm{ha}$ in May (28\% of the total yield) and total of $1890 \mathrm{~kg} / \mathrm{ha}$ of raw Cashewnut. Average price obtained by the farmers was Rs. 153.20per $\mathrm{kg}$ of nuts. Farmers realized higher gross return of Rs. 3,44,700 and net return of Rs. 2,79,206. It is observed that in both the districts, April month was the highest harvest month.

Sindhudurga district was the one where farmers got highest yield, highest gross returns and highest net returns. This might be due to more favourable soil and climatic conditions favoring the cashew plants than in Ratnagiri district and also price per kg nuts is highest in Sindhudurga district due the fact that prices prevailed in Goa markets are more than in local markets and also Goa is nearer to Sindhudurga district. If the price is lower here in Sindhudurga, farmers would send their produce to Goa markets.
Financial feasibility of investment in cashewnut production in Maharashtra

The foregoing results presented in the Table 6 revealed that the Net Present Values at 12 per cent discount rate for the entire life period of the cashew (20 years) were positive for both Ratnagiri and Sindhudurga districts and the NPV was found to be highest in Ratnagiri (Rs. 9,72,207) than in Sindhudurga (Rs. $11,38,561)$. The Benefit cost ratio was 3.95in Ratnagiri and 3.86 in Sindhudurga. However, the ratios were greater than unity for both the districts indicating remunerative returns per rupee of investment in cashew. The internal rate of returns was found to be 65.68percent in Ratnagiri, while in Sindhudurga, it was 68.73 percent. In both the districts, the internal rate of return was observed to be above the current bank rate and it was higher in Sindhudurga compared to Ratnagiri. Thus, the results of this study justified farmers' investment in cashew cultivation. The Pay Back Period was found to be lower in Sindhudurga i.e. 5.6 years whereas in Ratnagiri it was 5.7 years. Therefore investment on cashew would be recovered before 5.7 years at 12 percent rate of interest in both districts. The financial feasibility results of the present study are in line with the cultivation of cashew in Ratnagiri and Sindhudurga district of Maharashtra.

In conclusion, cashew cultivation provides excellent opportunities in raising the income of the farmers even in the dry tracts and thereby at national level by the way of export. Even though Maharashtra state has more area under cashew still there is more scope to increase the cashew area. With this intension in mind, an attempt was made to assess the economics of cashew cultivation in Maharashtra state. The study implied that in Maharashtra both area and production showed positive trends over the years but there is a slight declining trend in yield over the years. 
Therefore a prompt attempt should be made by the research and extension personnel in this regard. Study revealed that establishment cost of plantation is highly expensive. Hence farmers should be provided with required credit at reasonable rate of interest. Since there is high labour requirement and higher wage rate, there is a scope to evolve labour saving technologies. Study also revealed that cashew cultivation is highly profitable venture and is also financially feasible to establish new plantations in the study area.

\section{References}

Elakkiya, E., Sivaraj, P. and Vijayaprabhakar, A. 2017. Growth and Performance of Cashew Nut Production in India- An Analysis. International Journal of Current Microbiology and Applied Sciences. 6(6):1817-1823.

Gittinger, J. Price. 1974. Economic analysis of agricultural projects. Economic Development Institute, International Bank for Reconstruction Development, Washington D. C., USA.

Guledagudda, S. S. 2005. Production and Export Performance of Cashew - An Economic Analysis. Ph. D. Thesis. University of Agricultural Sciences, Dharwad. Karnataka.

Harish Kumar, K. 2009. An Economic Analysis of Processing and Export Trade of Cashew. M. Sc. Thesis. University of Agricultural Sciences, GKVK, Bengaluru. Karnataka.

Kulkarni, B. S., Ramachandra, V. A. and Patil, S. M. 2012. Trends in area, production and productivity of cashew in India - An economic analysis. International Journal of Commerce and Business Management. 5(2):128-133. www.indiastat.com

\section{How to cite this article:}

Mahantesh Nayak and Manjunatha Paled. 2018. An Economic Analysis of Cashewnut Production in Konkan Region of Maharashtra, India. Int.J.Curr.Microbiol.App.Sci. 7(12): 3079-3087. doi: https://doi.org/10.20546/ijcmas.2018.712.352 